\title{
Technical drawing
}

\section{Dibujo técnico}

JIMÉNEZ-RABIELA, Homero†*, VÁZQUEZ-GONZÁLEZ, Benjamín, RAMÍREZ-CRUZ, José Luis and BRAVO-ACOSTA, Adrian Gustavo Universidad Autónoma Metropolitana, Unidad Azcapotzalco, División de Ciencias Básicas e Ingeniería, Departamento de
Energía

ID $1^{\text {st }}$ Author: Homero, Jiménez-Rabiela / ORC ID: 0000-0002-1549-0853, Researcher ID Thomson: S-2299-2018, CVU CONACYT ID: 123386

ID $1^{\text {st }}$ Co-author: Benjamín, Vázquez-González / ORC ID: 0000-0002-9030-5662, Researcher ID Thomson: S-2417-2018, CVU CONACYT ID: 25749

ID $2^{\text {nd }}$ Co-author: José Luis, Ramírez-Cruz / ORC ID: 0000-0003-0762-2630, Researcher ID Thomson: G-3405-2019, CVU CONACYT ID: 921268

ID $3^{\text {rd }}$ Co-author: Adrian Gustavo, Bravo-Acosta / ORC ID: 0000-0001-57975317, Researcher ID Thomson: 2272-2018, CVU CONACYT ID: 334391

DOI: $10.35429 / J O T E .2021 .15 .5 .7 .14$

Received July 10, 2021; Accepted December 30, 2021

\begin{abstract}
The objective of this work is to propose the use of didactic material, to facilitate the teaching and learning of orthogonal projections in the international system. Virtual files of the projection planes are created: front, left side and bottom; as well as those corresponding to three versions of the same geometric entity: point, line, area and solid. The frontal plane is fixed, and the left side and bottom are restricted with respect to it allowing its rotation to coplanar all three. In the assembly of the projection planes, versions 1,2 and 3 of the same geometric entity are inserted; each one respectively including its frontal, right lateral and superior projections; such versions are restricted with respect to the frontal, left side and bottom plane. The restrictions between the projection planes and between them and the versions of the same geometric entity allow the animation of the assembly, showing the solution of the problem that involves representing a three-dimensional object on a sheet. The augmented, virtual, animated, and timed reality environment; according to the learning needs of students and teaching of teachers; constitutes the main contribution of this work.
\end{abstract}

Didactics, Drawing, Technical

\begin{abstract}
Resumen
El objetivo de este trabajo es proponer el uso de material didáctico, para facilitar la enseñanza y el aprendizaje de las proyecciones ortogonales en sistema internacional. Se crean archivos virtuales de los planos de proyección: frontal, lateral izquierdo e inferior; así como aquellos correspondientes a tres versiones de una misma entidad geométrica: punto, línea, área y sólido. El plano frontal se fija, y el lateral izquierdo e inferior se restringen con respecto a él permitiendo su rotación para hacer coplanares a los tres. En el ensamble de los planos de proyección se insertan las versiones 1,2 y 3 de una misma entidad geométrica; cada una de ellas incluyendo respectivamente su proyección frontal, lateral derecha y superior; tales versiones se restringen con respecto al plano frontal, lateral izquierdo e inferior. Las restricciones entre los planos de proyección y entre éstos y las versiones de una misma entidad geométrica permiten la animación del ensamble, mostrando la solución del problema que implica representar en una hoja un objeto tridimensional. El ambiente de realidad aumentada, virtual, animada y temporizada; de acuerdo con las necesidades de aprendizaje de alumnos y de enseñanza de profesores; constituye la principal contribución de este trabajo.
\end{abstract}

Didáctica, Dibujo, Técnico

Citation: JIMÉNEZ-RABIELA, Homero, VÁZQUEZ-GONZÁLEZ, Benjamín, RAMÍREZ-CRUZ, José Luis and BRAVO-ACOSTA, Adrian Gustavo. Technical drawing. Journal of Technical Education. 2021, 5-15: 7-14

\footnotetext{
* Correspondence to Author (e-mail: hjr@azc.uam.mx)

$\dagger$ Researcher contributing first author.
} 


\section{Introduction}

The representation of the shape and dimensions of parts or sets of these, as well as their correct interpretation through the analysis of their corresponding drawings, allows optimizing the mass production of parts, machines, equipment, instruments and devices. Representing a threedimensional object on a sheet of paper involves projecting it in orthogonal frontal, left lateral and inferior planes and rotating the latter two to make them coplanar with the first. See the process with complete clarity is not easy for most students, futures professionals of engineering. Starting from the hypothesis that all reality can be virtually augmented, an innovative solution to the aforementioned problem is presented.

Different geometric entities are represented in the orthogonal projection planes. During the process of turning two of them, the projections and a representation of the entity itself rotate with the corresponding projection plane, to show kinematically and objectively the steps of the process; with or without breaks and with discretization adapted to the user's visual and cognitive capacity; at the limit when there are no breaks and the discretization tends to zero can be viewed as continuous. The presentation in an augmented reality environment constitutes the added value with respect to other techniques. Orthogonal projections are important as they represent the language of communication for engineers, architects, and designers, to manufacture parts or machines for industrial purposes. Its knowledge with sufficient extension and depth is essential for the professionals mentioned in the formative stage.

Knowing its importance, Ramírez, O. et al (2018) presented at the VI Argentine Congress of Mechanical Engineering and I Argentine Congress of Railway Engineering the article teaching resources for the teaching of technical drawing; in which they show the design of a real device that must be operated manually by the teacher, or the student, facilitating the understanding of the process of projecting the object on the planes and the rotation of two of them to obtain a twodimensional representation of an object threedimensional. Paz, J. (2013)
In his article, he stated as an objective to contribute to the increase in the efficiency of the teaching-learning process of the subject Technical Drawing with the application of a didactic strategy in the College of Scientific and Technological Studies Plantel "Las Varas"; State of Nayarit based on an approach oriented to the training and development of competencies, based on Developer Didactics for problem solving. The Colombian Institute of Technical Standards and Certification (2002) in the Technical Drawing Compendium included the chapter general principles of presentation, in which it describes the projection method of the first and third quadrant.

The second section of the present work describes the components used to solve the problem, their assembly is explained in the third, in the fourth the animations to facilitate teaching and learning are explained, the results are described in the fifth, in the sixth it is the annexes indicate.

\section{Components}

Projection planes (PP):

FRONT PLANE (PF)

LEFT SIDE PLANE (PLI)

LOWER PLANE (PI)

Geometric entities (EG):

POINT (P)

STRAIGHT (R)

AREA (A)

SOLID (S)

There will be as many triads of projection planes as there are geometric entities. For each triad of projection planes there will be 3 versions of the geometric entity (V1, V2 and V3). If we use the abbreviations, the projection planes are PF P, PLI P, PI P, PF R, PLI R, PI R, PF A, PLI A, PI A, PF S, PLI S and PI S; the geometric entities are P V1, P V2, P V3, R V1, R V2, R V3, A V1, A V2, A V3, S V1, S V2, and S V3. Additionally there will be a component called the observer's visual ray (RVO), which will be used for the three projections.

All components are Normal (mm) .ipt, a $\mathrm{PP}$ and an EG, respectively, shown in Figures 1 and 2 . 


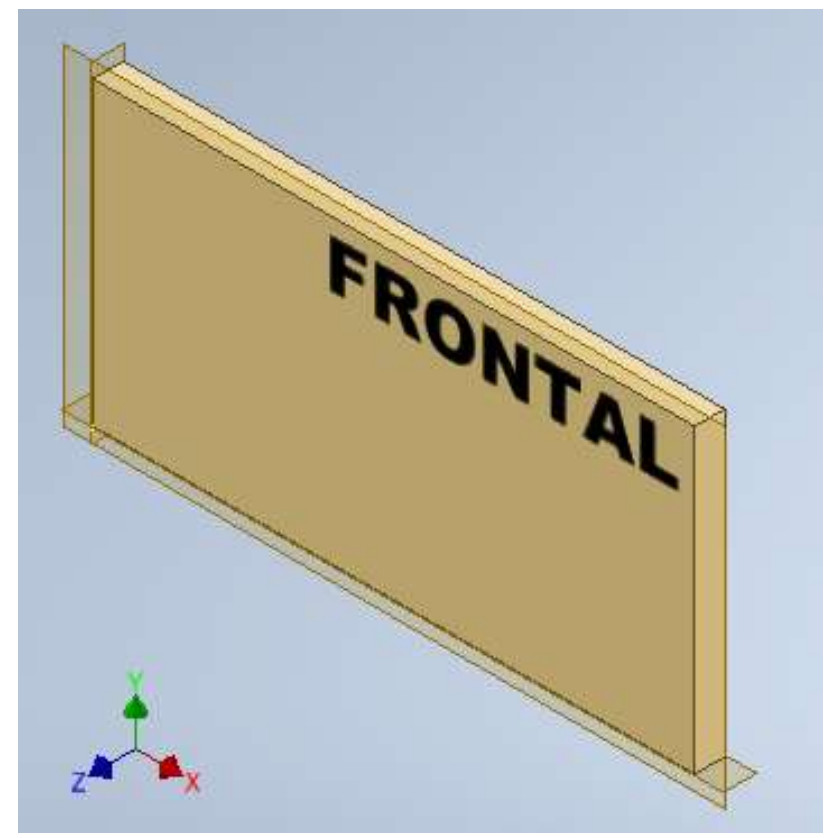

Figure 1 PF P

Source: Own Ebaloration

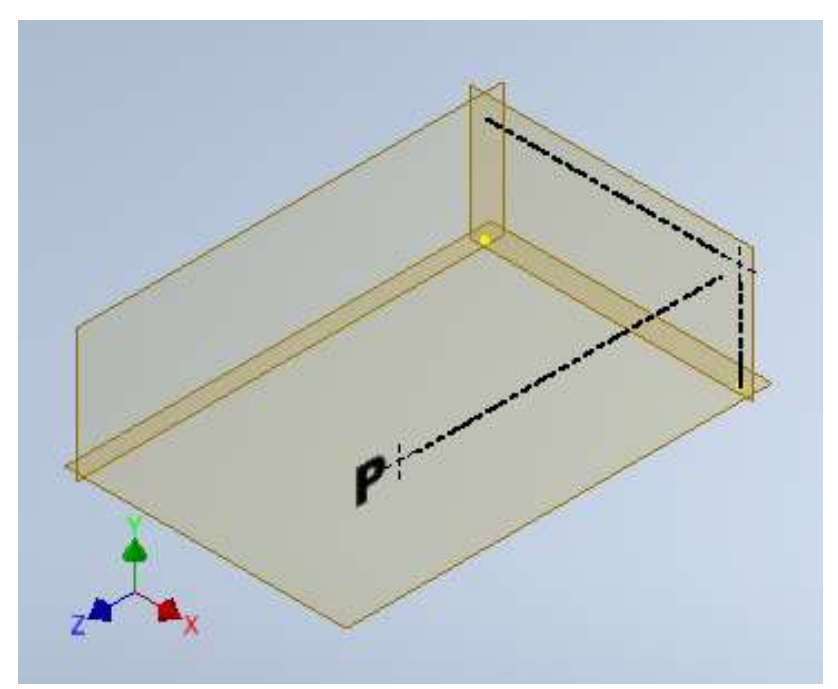

Figure $2 \mathrm{P}$ V1

Source: Own Ebaloration

Note the location of the PP relative to their PCs (transparent) and the location of the EG relative to their PCs (transparent). The geometric entity to project, its projection and interrupted orthogonal lines constitute one piece. Each of the 25 components has its own coordinate planes (PC). All Figures include the coordinate system at the bottom left.

\section{Assemble}

There will be as many assemblies (ASSEMBLY P, ASSEMBLY R, ASSEMBLY A, ASSEMBLY S) as EG. All PFs will be fixed. Figures 3, 4 and 5 show the constraints of a PLI with respect to the corresponding PF. All PLIs have the same restrictions with respect to their corresponding PF.

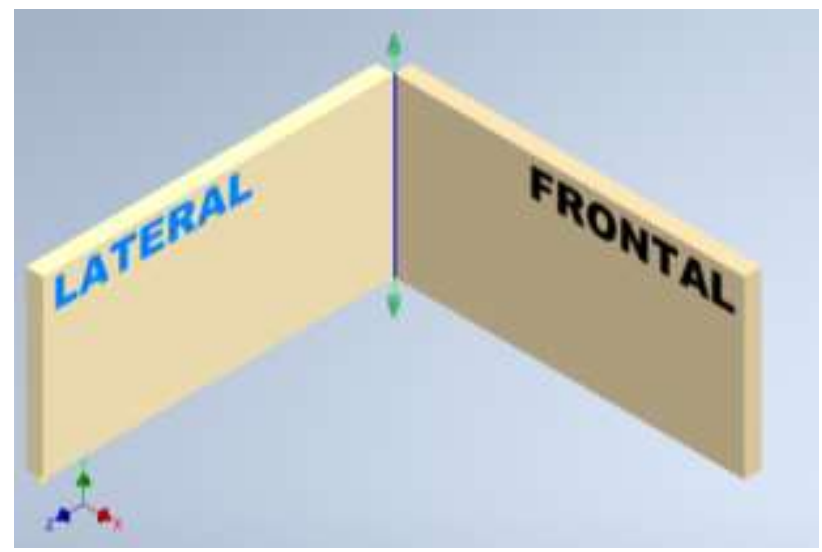

Figure 3 Coincidence PLI P and PF P Source: Own Ebaloration

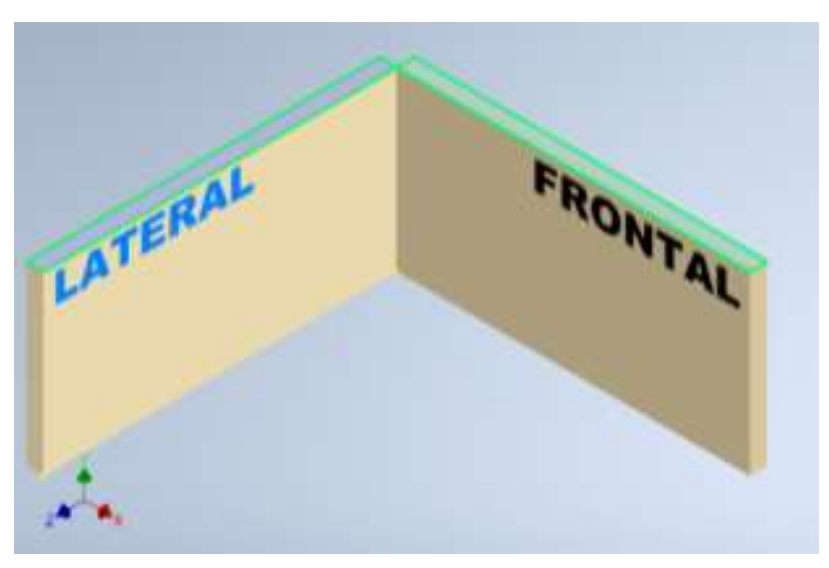

Figure 4 Leveling PLI P and PF P Source: Own Ebaloration

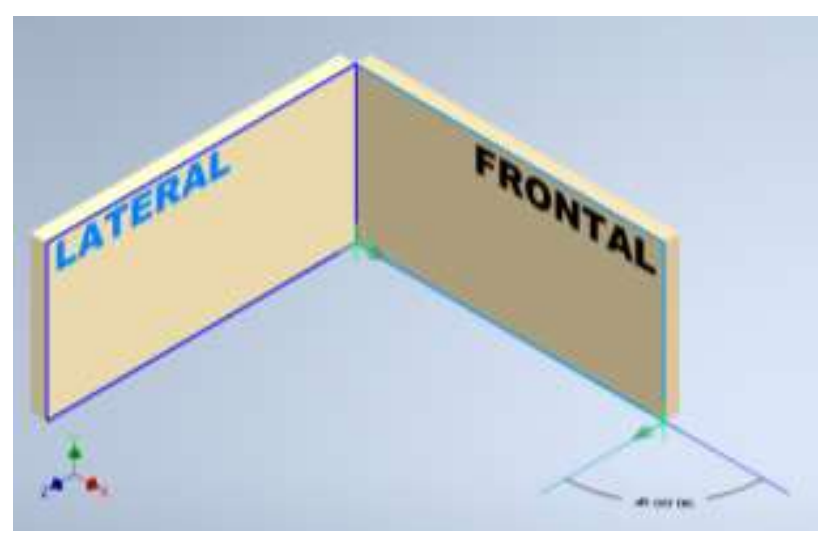

Figure 5 Angle PLI P and PF P Source: Own Ebaloration

Figures 6, 7 and 8 show the restrictions of a PI with respect to its corresponding FP. Every PI has the same restrictions with respect to its corresponding frontal plane. 


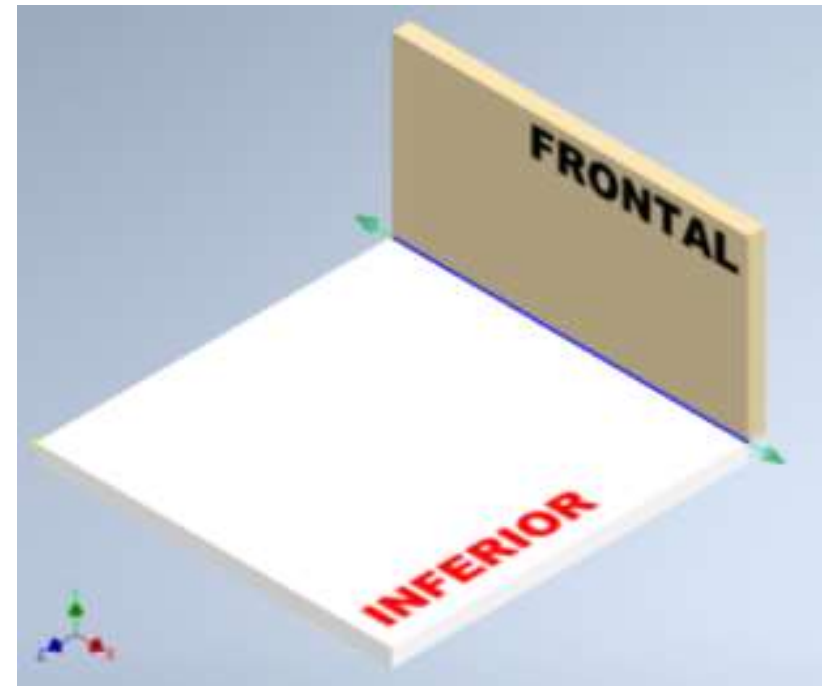

Figure 6 Coincidence PI P and PF P Source: Own Ebaloration

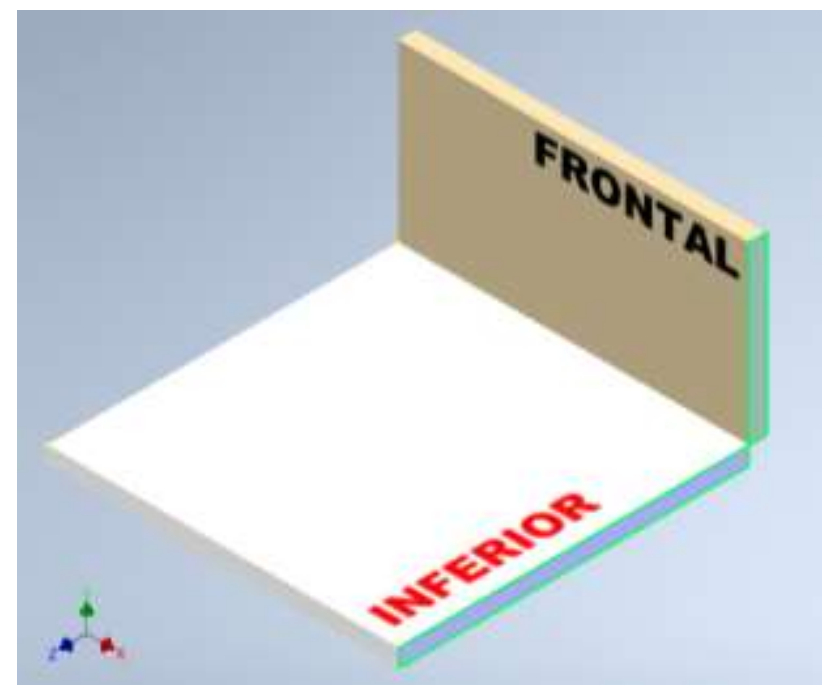

Figure 7 Leveling PI P and PF P Source: Own Ebaloration

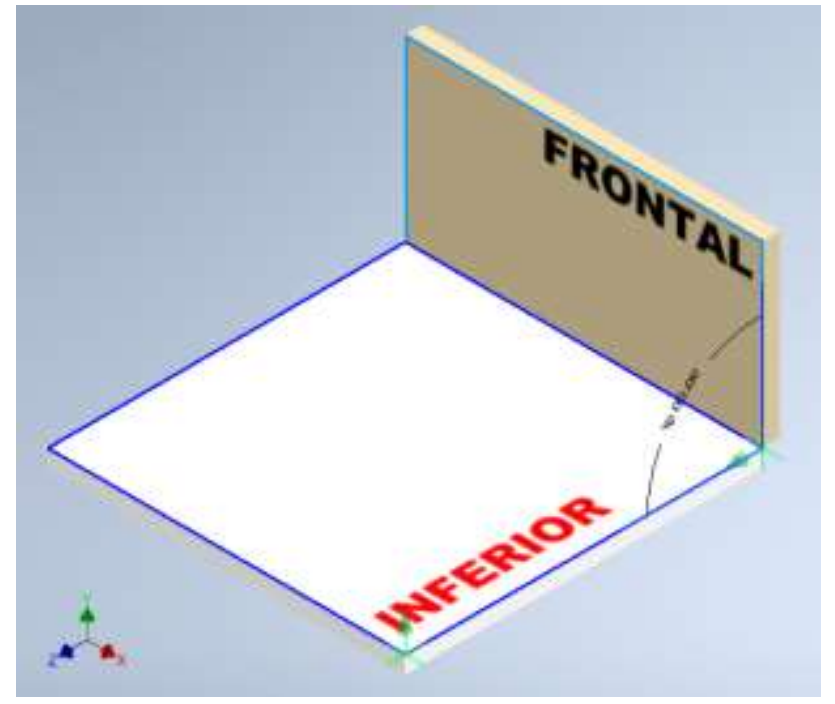

Figure 8 Angle PI P and PF P Source: Own Ebaloration

Figure 9 shows the relative position of the V1 of an EG with respect to the corresponding PF. The PCs of the first are coplanar with the corresponding PCs of the second.
The PCs of V2 of the same EG are coplanar with the corresponding PCs of the corresponding PLI. The PCs of version 3 of the same EG are coplanar with the corresponding PCs of the corresponding PI.

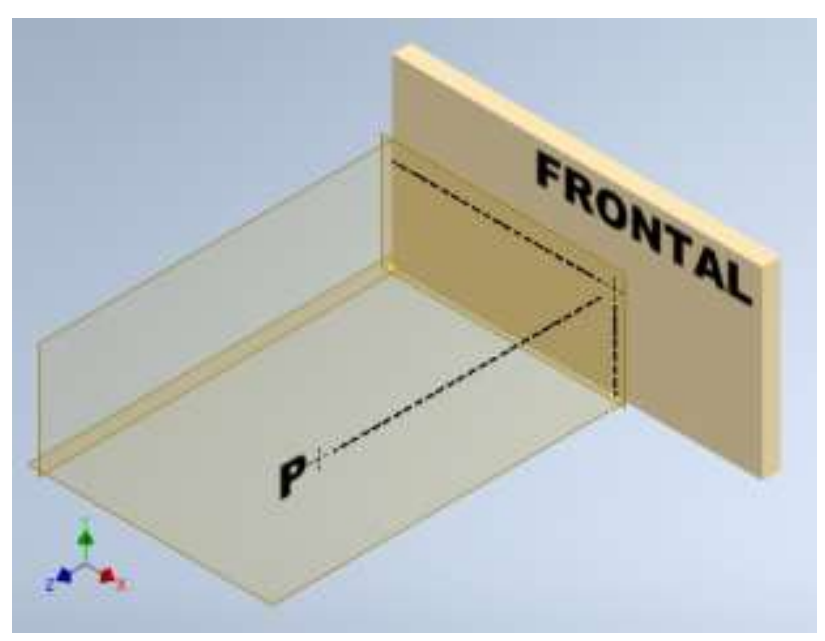

Figure 9 Position P V1 and PF P Source: Own Ebaloration

The relative positions of each of the versions of the EG with respect to its corresponding PP are shown in Figure 10.

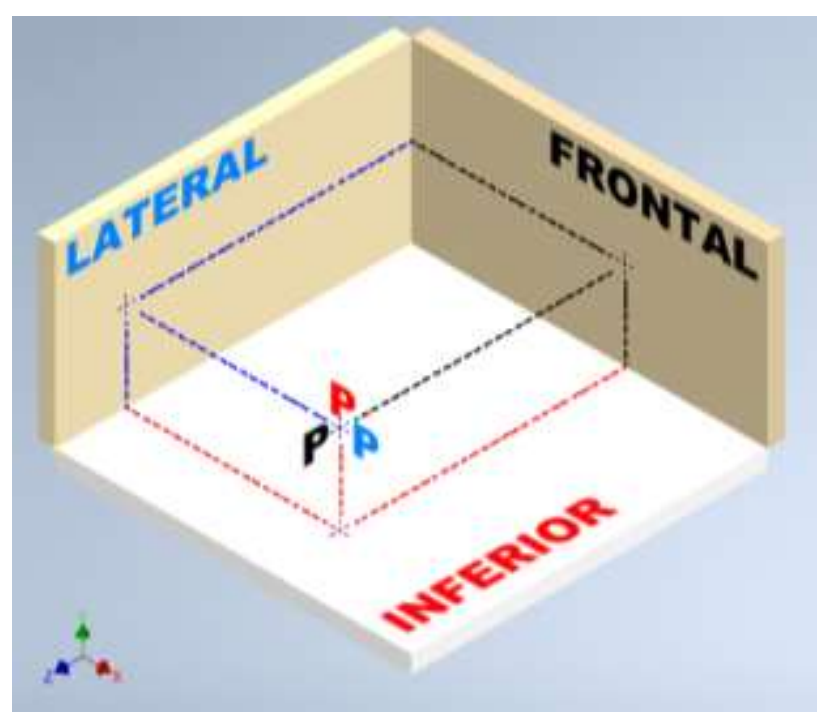

Figure $10 \mathrm{P}$ V1, 2y3 - PP

Source: Own Ebaloration

The relative positions, of each of the versions of all EG, with respect to their corresponding PP are analogous.

\section{Animations}

In each assembly, by changing the 90 degree angle to zero; between the PLI and the PF, rotate the first to position itself coplanar with the second dragging to the V2 of the EG. 
When changing the 90 degree angle to zero; between PI and PF, rotate the first to position itself coplanar with the second dragging to the V3 of the EG. The result is shown in Figure 11.

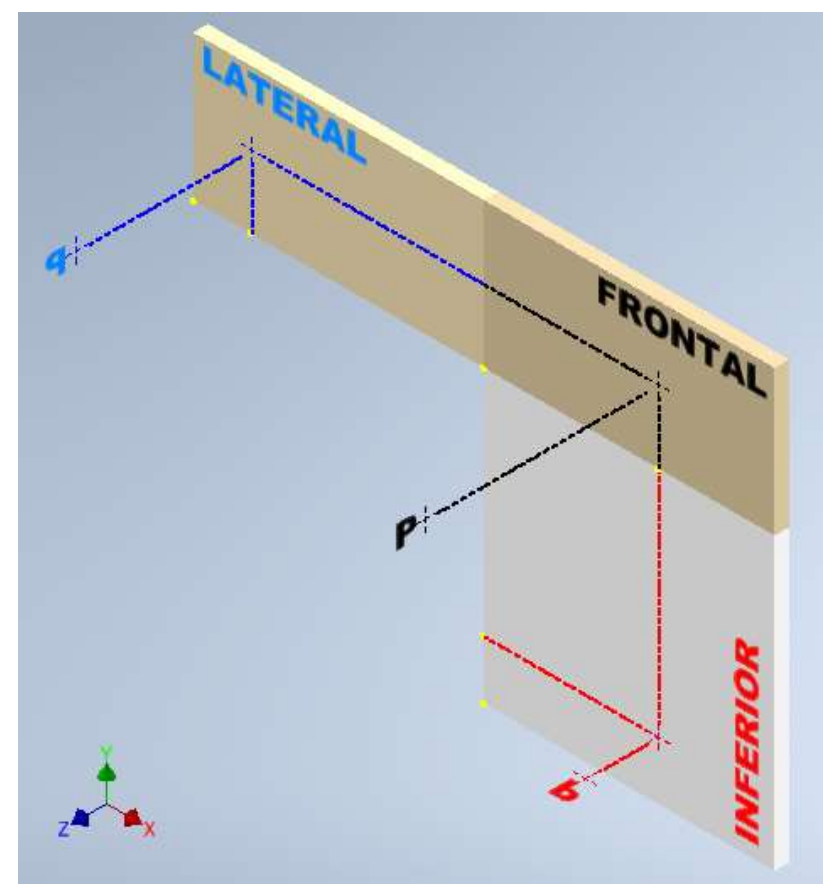

Figure 11 Coplanar drawings

Source: Own Ebaloration

Starting from the EG and PP position shown in Figure 11, animate the angles from zero to 90 degrees, with or without a pause and with the most suitable discretization for the user; The video will show the solution of the problem objectively. From Figures 12 to 15, each pair of them shows the projections of a line and an area.

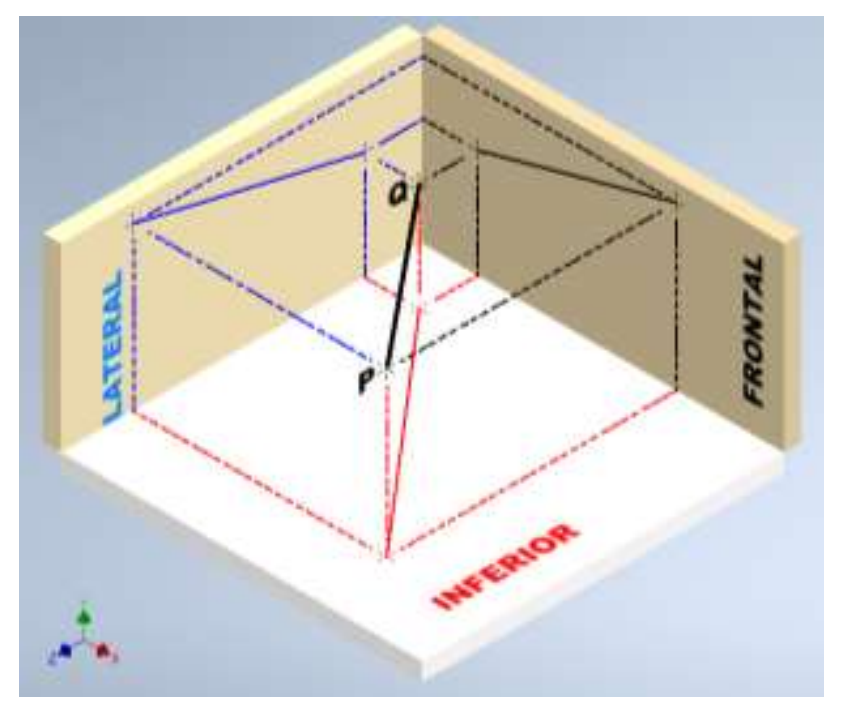

Figure 12 Projections of $\mathrm{R}$ Source: Own Ebaloration

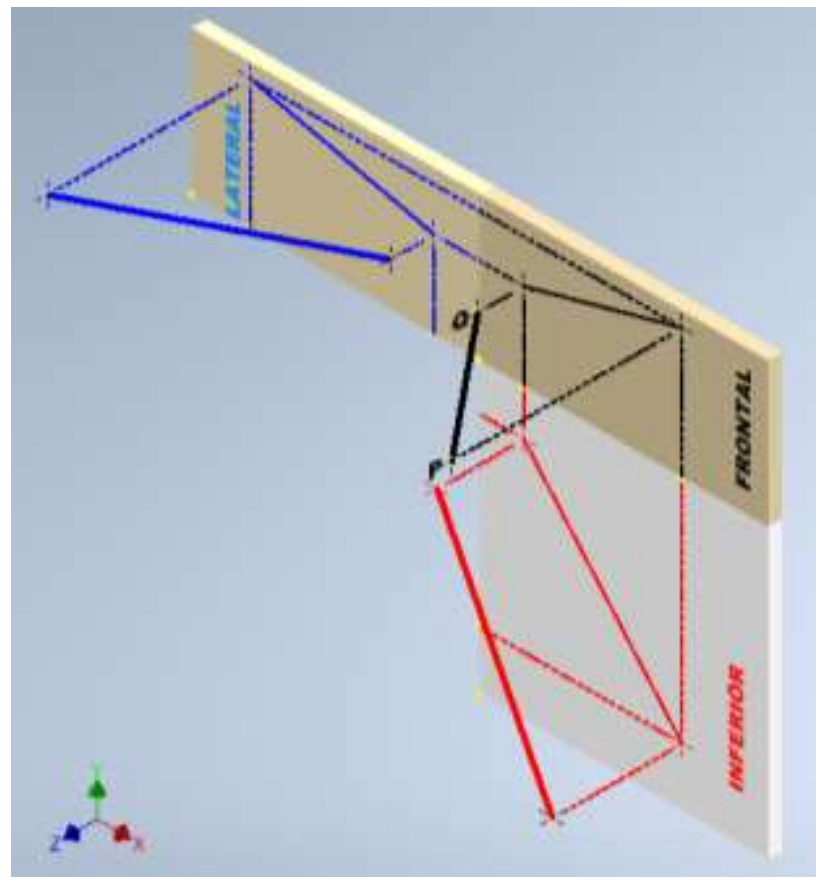

Figure 13 Projections of $\mathrm{R}$ Source: Own Ebaloration

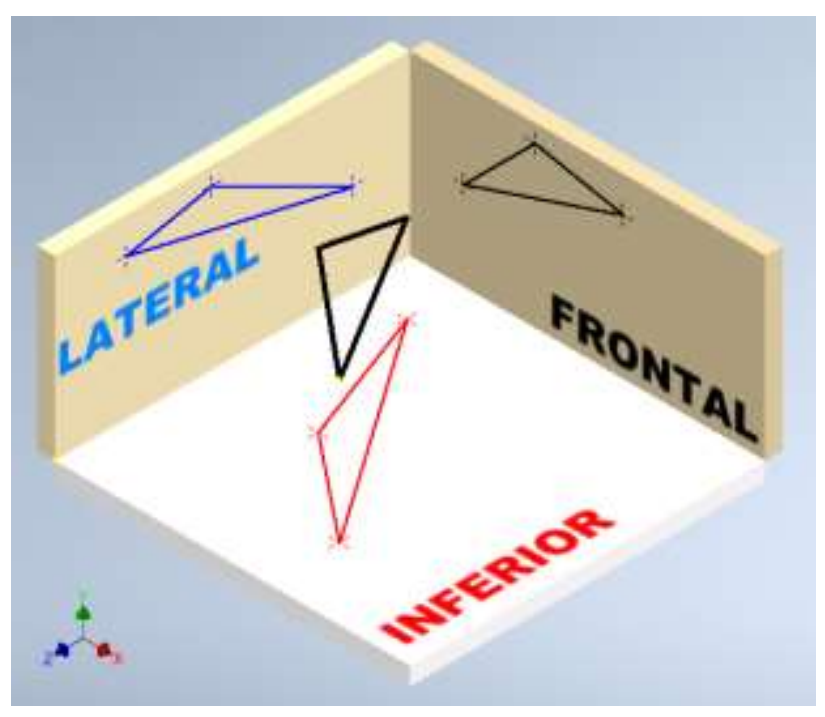

Figure 14 Projections of $\mathrm{A}$ Source: Own Ebaloration 


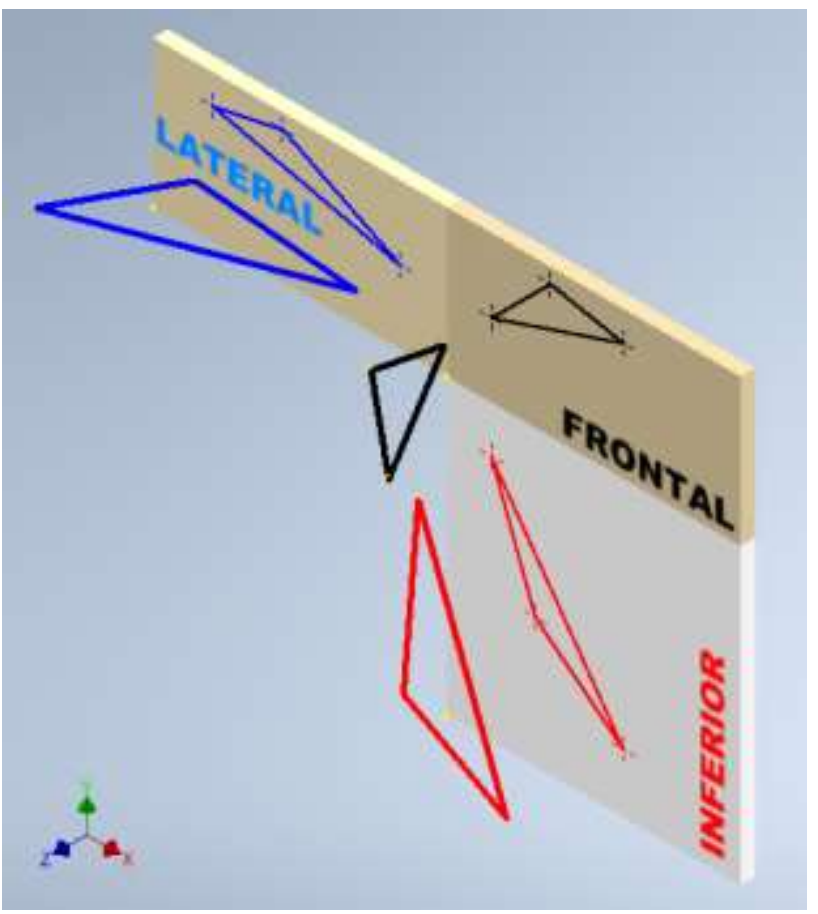

Figure 15 Projections of A Source: Own Ebaloration

Figures 16 through 21 show the projections of a solid.

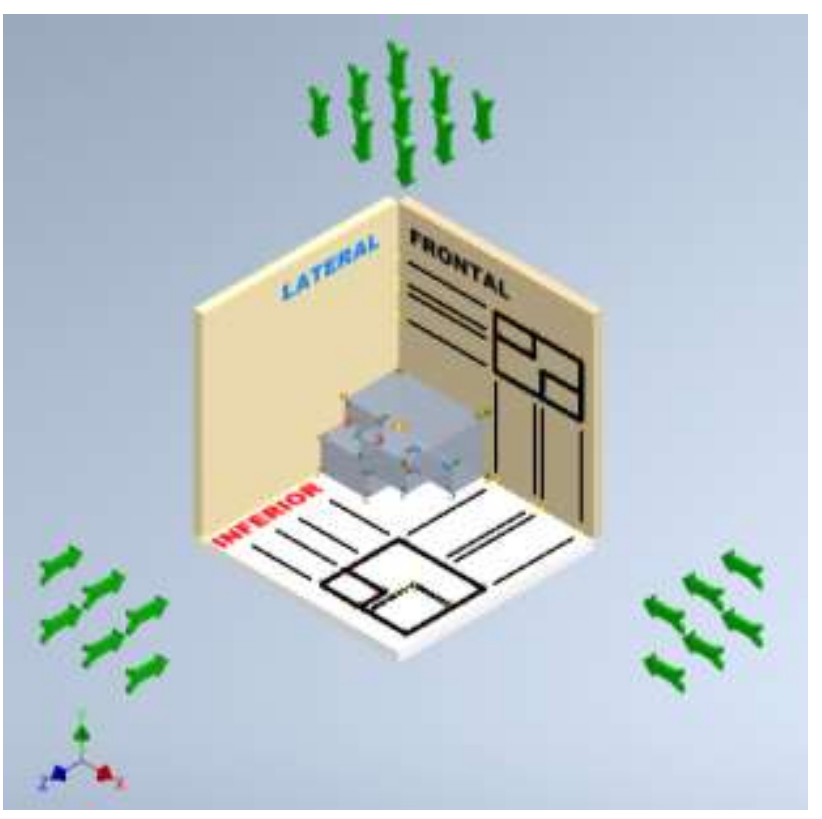

Figure 16 Projections of $\mathrm{S}$

Source: Own Ebaloration

The green arrows represent the observer and are perpendicular to the corresponding PP.

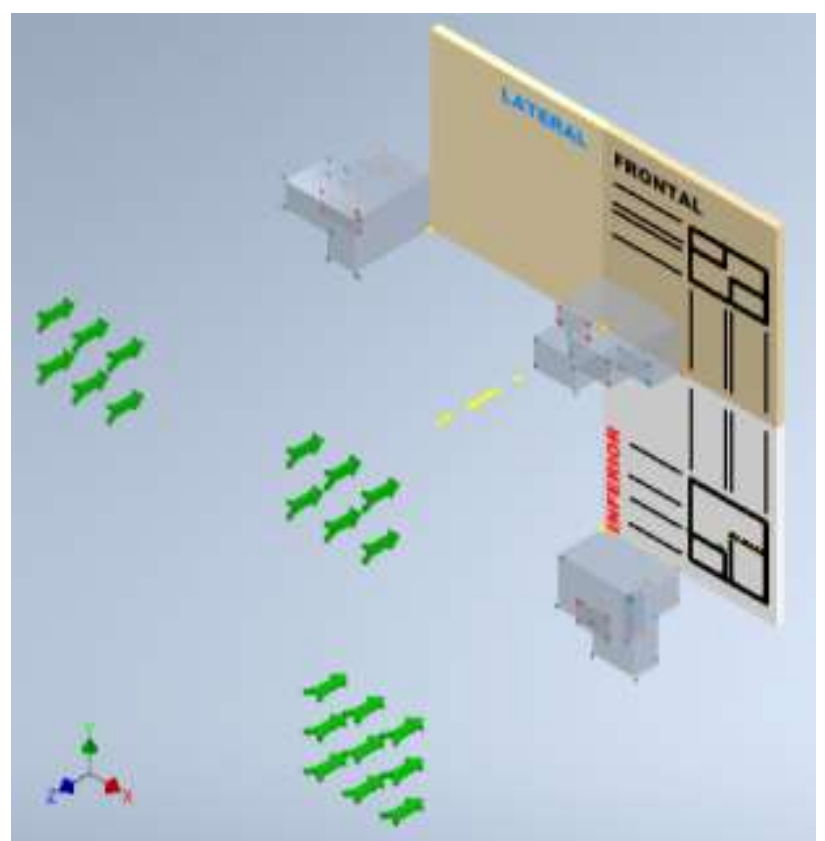

Figure 17 Solid projections Source: Own Ebaloration

Note that when rotating the PP they also drag the corresponding observer.

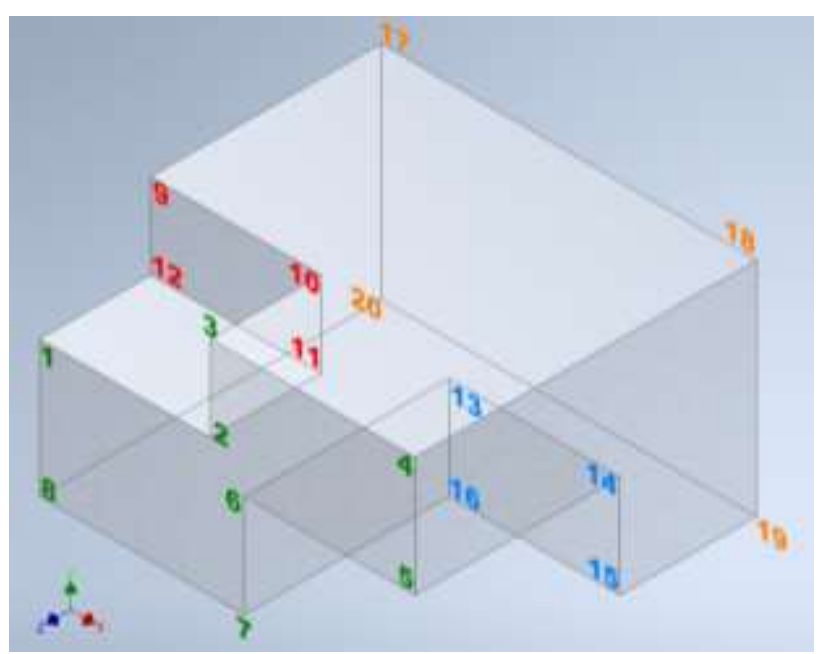

Figure 18 Vertices of S V1

Source: Own Ebaloration

The solid shown in the previous Figure should be visualized as a prism with a rectangular base, with part of its upper left corner removed and part of its lower right corner removed. The colors of the numbers are used to differentiate the distance of the observer with respect to the vertices; green less distance, orange greater distance, red greater distance than green and less distance than blue.

The vertices of the solid in its three versions are assigned the same number; however, the color will change depending on the version, keeping the meaning of the colors with respect to the distance from the vertex to the corresponding observer.

JIMÉNEZ-RABIELA, Homero, VÁZQUEZ-GONZÁLEZ, Benjamín, RAMÍREZ-CRUZ, José Luis and BRAVO-ACOSTA, Adrian Gustavo. Technical drawing. Journal of Technical Education. 2021 


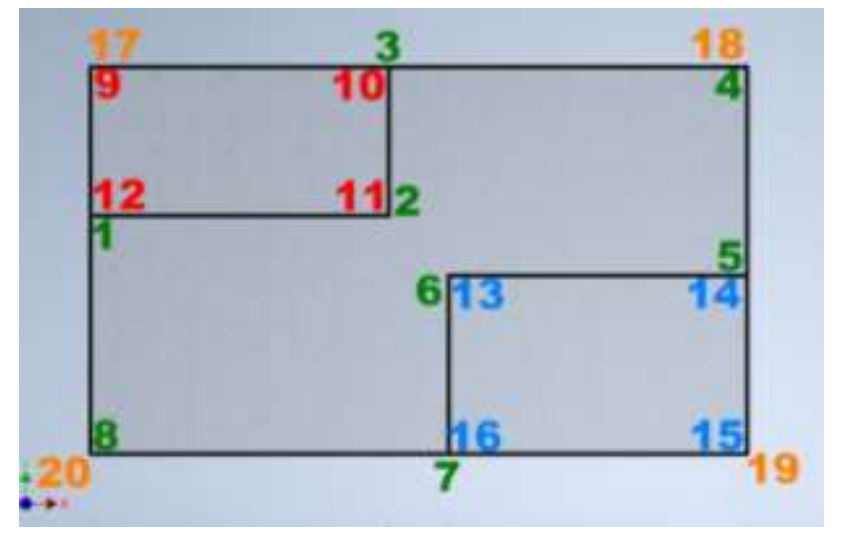

Figure 19 Projections of S V1

Source: Own Ebaloration

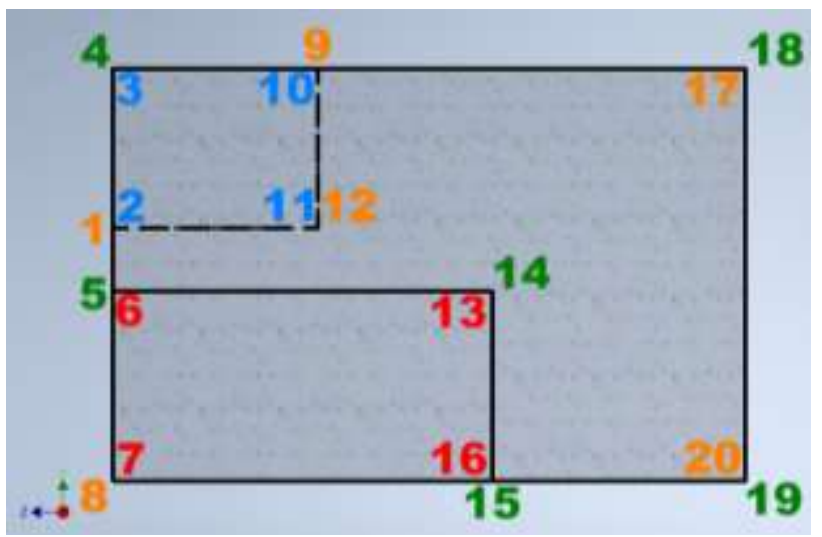

Figure 20 Projections of S V2

Source: Own Ebaloration

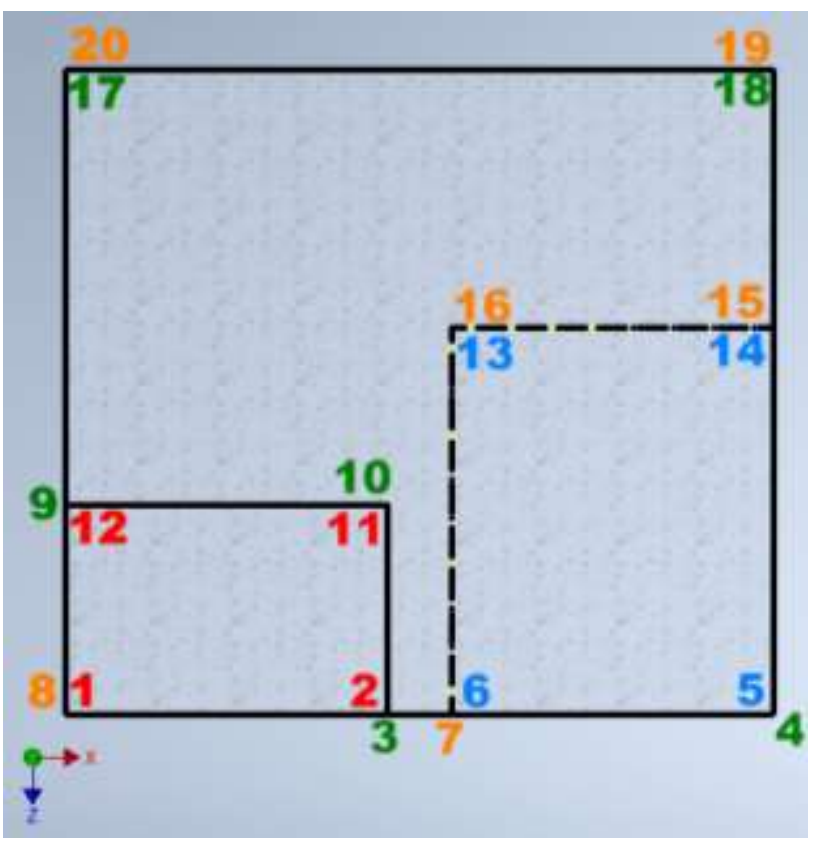

Figure 21 Projections of S V3

Source: Own Ebaloration

\section{Results}

The animations to rotate the left and lower lateral planes and make them coplanar with the frontal plane were carried out by dragging the corresponding geometric entity integral with its projection.
The previous result was possible due to the restrictions used in the assembly of components: the planes with freedom of rotation with respect to the frontal plane and the geometric entities in their version 1,2 and 3 with respect to the frontal, left lateral and inferior plane, respectively. The dragging of the version of the geometric entity and its corresponding projection was possible thanks to the integration of both as a single piece. Integrating the results of the sections, the problem raised was solved in an environment of augmented, virtual, animated and timed reality; according to the learning needs of students and teachers' teaching.

\section{Annexes}

The 25 component files, the four assembly files and the video corresponding to the solid assembly are attached.

\section{Acknowledgments}

The authors are grateful for the institutional support of the Universidad Autónoma Metropolitana and the Azcapotzalco Unit, in particular the Division of Basic Sciences and Engineering and the Department of Energy.

\section{Conclusions}

Integrating the results of the sections, the problem raised was solved in an environment of augmented, virtual, animated and timed reality; according to the learning needs of students and teachers' teaching. The files included in annexes facilitate the teaching-learning process. To enhance the learning process, design a set of parts and assembly files; exprofeso for student exercises.

\section{References}

Ramírez, O. Fernández, M. \& Tévez, E. (2018, octubre 12). RECURSOS DIDÁCTICOS PARA LA ENSEÑANZA DEL DIBUJO TÉCNICO. Revista del VI CONGRESO ARGENTINO DE INGENIERÍA MECÁNICA., 1, pp 1-12.

Paz, J. (2013, mayo 28). Una propuesta de estrategia didáctica para el proceso enseñanzaaprendizaje del Dibujo Técnico. Dilemas contemporáneos: educación, política y valores, 1 , pp $1-36$. 
Instituto Colombiano de Normas Técnicas y Certificación. (2002). Compendio de Dibujo Técnico. Colombia: Diseño y Diagramación: Servicios de Diseño ICONTEC, pp 47-72. 